\title{
MANAJEMEN STRATEGIK MUTU REKRUTMEN TENAGA KEPENDIDIKAN DI INSTITUT AGAMA ISLAM NEGERI MADURA
}

\author{
Robby Arini dan Achmad Muhlis \\ Institut Agama Islam Negeri Madura \\ E-mail: robby4r1n1.jhubeg@gmail.com dan muhlis.ach75@gmail.com
}

\begin{abstract}
Abstrak
Artikel ini mendeskripsikan pelaksanaan manajemen strategik mutu rekrutmen tenaga kependidikan di Institut Agama Islam Negeri Madura. Institut Agama Islam Negeri sebagai salah satu Institut pendidikan yang pada awalnya hadir dilatarbelakangi oleh kebutuhan masyarakat akan pendidikan yang lebih tinggi untuk kemudian hasilnya akan dikembalikan kepada masyarakat. Sehingga untuk menjamin mutu lulusan perlunya merekrut tenaga kependidikan yang memiliki mutu sehingga menjamin keberhasilan pendidikan yang diharapkan. Manajemen strategik mutu rekrutmen tenaga kependidikan di Institut Agama Islam Negeri Madura selama ini baik cukup baik, meskipun ada beberapa hal yang perlu ditingkatkan kaitannya dengan bentuk manajemen strategik mutu rekrutmen tenaga kependidikan di Institut Agama Islam Negeri Madura yang cukup baik hal ini terlihat dari beberapa hal, yakni: mutu rekrutmen, sumber rekrutmen. Lalu untuk implementasi manajemen strategik mutu rekrutmen tenaga kependidikan di Institut Agama Islam Negeri Madura lebih pada: Sumber daya manusia yang terlibat dalam rekrutmen, kendala dalam rekrutmen.
\end{abstract}

Kata Kunci: Manajemen Strategik, Mutu Rekrutmen, Tenaga Kependidikan

\begin{abstract}
This article describes the implementation of quality management strategic recruitment of education personnel in the state islamic institute of madura. State islamic institute of madura as one of the earliest educational institutes which was present based on the background of the community's need for higher education and then the results will be returned to the community. so as to ensuring the quality of graduates it is necessary to recruit the quality of education personnel so that ensuring the expected educational success.strategic management of the recruitments quality of education personnel in the state islamic institute of madura so far is good enough, although there are some things that need to improved with the form of recruitment strategic management of education personnel in the state islamic institute of madura is good enought. It can be seen from several things, namely : quality of recruitment, source of recruitment. Than for the implementation of recruitment strategic management of the quality education personnel in the state islamic institute of madura more on : human resources seen in recruitment and constraints in recruitment.
\end{abstract}

Keywords: Strategic Management, Recruitment Quality, Education Personnel 


\section{PENDAHULUAN}

Rendahnya kualitas sumber daya manusia merupakan masalah mendasar yang dapat menghambat pembangunan dan perkembangan ekonomi nasional. Oleh karena itu, diperlukan sumber daya manusia berkualitas yang memiliki kemauan dan kemampuan untuk senantiasa meningkatkan kualitasnya secara terus menerus dan berkesinambungan (continuous quality improvement). ${ }^{1}$ Rekrutmen sebagai suatu proses pengumpulan calon pemegang jabatan yang sesuai dengan rencana pegawai untuk menduduki suatu jabatan tertentu dalam fungsi pekerjaan (employee fuction) pegawai selama ini di atur dalam Peraturan Pemerintah (PP) Nomor 98 Tahun 2000 tentang Pengadaan Pegawai Negeri Sipil sebagaimana telah diubah dengan PP Nomor 11 Tahun 2002 dan PP Nomor 97 Tahun 2000 tentang formasi pegawai negeri sipil sebagaimana telah diubah dengan PP Nomor 54 Tahun 2003 serta PP Nomor 100 Tahun 2000 tentang Pengangkatan Pegawai Negeri Sipil dalam Jabatan Struktural sebagaimana telah diubah dengan PP Nomor 13 Tahun 2000. Penerapan kebijakan tersebut sebenarnya bertujuan untuk memperoleh pegawai yang berkualitas, yakni pegawai yang pintar, terampil dan memiliki kompetensi, dapat bekerja keras, kreatif dan bermoralitas tinggi. Oleh karena itu, peningkatan kualitas sumber daya manusia merupakan kenyataan yang harus dilakukan secara terencana, terarah, intensif, efektif dan efisien dalam proses pembangunan. $^{2}$

Sejalan dengan peraturan tersebut maka organisasi sebelum merekrut sumber daya manusia (tenaga kependidikan) harus memiliki standar tersendiri untuk mengisi posisi yang kosong dalam organisasi tersebut apalagi dalam organisasi pendidikan, karena semakin tinggi standar yang dimiliki oleh suatu organisasi maka semakin maju pula suatu organisasi tersebut. Keberhasilan ditentukan oleh sumber daya manusia yang berperan di dalamnya, jika rekrutmen yang dilakukan oleh lembaga sudah tidak memiliki mutu yang baik maka tenaga kependidikan yang dihasilkan pun tidak akan bekerja secara maksimal dan untuk mencapai tujuan lembaga akan mengalami hambatan.

Seperti halnya dalam suatu perguruan tinggi harus merumuskan standar tenaga kependidikan atau standar sumber daya manusia (SDM), dimana standar tersebut harus ditingkatkan secara terus menerus dari waktu ke waktu sehingga standar tersebut berkembang secara berkelanjutan (continous improvement). Semakin tinggi standar sumber daya manusia yang ditetapkan, semakin bermutu kondisi dosen dan tenaga penunjangnya. Standar ini merupakan acuan keunggulan mutu sumber daya manusia, serta bagaimana seharusnya sebuah program studi di suatu perguruan tinggi memperoleh dan mendayagunakan sumber daya manusia yang bermutu tinggi serta dapat memberikan layanan prima kepada sumber daya manusianya untuk mewujudkan visi, melaksanakan dan menyelenggarakan misi, dan mencapai tujuan yang dicitacitakan. $^{3}$

1 Ika Dewi Rahmawati, "Manajemen Sumber Daya Manusia (SDM) dalam Peningkatan Kualitas Sekolah.” Jurnal Manajemen Rekrutmen Tenaga Kependidikan, 2 (Oktober, 2012), hlm., 2.

2 Nani I. Rajaloa dan Rustan Hasim, "Manajemen Perencanaan dan Rekrutmen Tenaga Pendidikan oleh Dinas Pendidikan Kota Ternate.” Jurnal Pendidikan, Vol. 16, No. 1, (Januari, 2018), hlm., 11.

3 Yeni Nuraeni,’Perencanaan Sistem Informasi Penjaminan Mutu Perguruan Tinggi Bidang Sumber Daya Manusia." Journal of Information systems, Vol. 6, No. 1 (April 2010), hlm., 32. 
Seperti yang telah diatur dalam undang-undang UU No. 14 tahun 2005 tentang guru dan dosen, guru yang tadinya masuk rumpun "pendidik", kini telah memiliki definisi tersendiri. ${ }^{4}$ Secara lebih luas tugas tenaga kependidikan tertuang dalam Undang-undang sistem pendidikan nasional nomor 20 tahun 2003 BAB XI pasal 39 ayat 1 yang menyebutkan bahwa tenaga kependidikan bertugas melaksanakan administrasi, pengelolaan, pengembangan, pengawasan, dan pelayanan teknis untuk menunjang proses pendidikan pada satuan pendidikan. ${ }^{5}$ Mutu dalam lingkup pendidikan di perguruan tinggi memiliki arti bahwa fungsi, tujuan serta standar yang ditentukan dan di jalankan di lingkup perguruan tinggi telah sesuai, memenuhin syarat. Harapan dan kepuasan stakeholder perguruan tinggi yang tidak berbenah akan ditinggalkan oleh stakeholders. ${ }^{6}$ Upaya meningkatkan mutu pendidikan di sekolah memerlukan titik berangkat dari pola pemikiran yang memandang sekolah sebagai suatu sistem. Sekolah terdiri dari berbagai komponen yang saling berhubung, membutuhkan dan saling berinteraksi atara satu dengan yang lainnya. ${ }^{7}$

Untuk perekrutan pegawai tetap ini telah terlampir dalam keputusan Sekretaris Jenderal Kementerian Agama Nomor 6106 tahun 2018 tentang petunjuk pelaksanaan/teknis pengadaan calon pegawai negeri sipil Kementerian Agama tahun anggaran 2018. Secara umum dimuat bahwa: (1) Sesuai kebijakan pemerintah tentang pengadaan calon pegawai negeri sipil (CPNS) tahun 2018, diselenggarakan berdasarkan keputusan menteri PAN dan RB Nomor 49 tahun 2018 tentang penetapan kebutuhan pegawai negeri sipil Kementerian Agama tahun 2018, (2) Dalam upaya memperoleh sumber daya pegawai negeri sipil (PNS) yang berkualitas pada kementerian agama, perlu dilakukan seleksi administrasi, seleksi kompetensi dasar (SKD), seleksi kompetensi bidang (SKB), (3) Keputusan sekretaris jenderal kementerian agama ini mengatur tentang petunjuk pelaksanaan/teknis pengadaan calon pegawai negeri sipil tahun anggaran 2018.

Dalam dunia pendidikan manajemen strategi sangat dibutuhkan. Mengatur strategi yang dibuat dan direncanakan agar tujuan organisasi lembaga pendidikan yang dimaksud baik sekolah/madrasah dan perguruan tinggi dapat tercapai. Manajemen strategi pada umumnya dilakukan pada jangka menengah dan jangka panjang. Artinya bagaimana suatu lembaga atau madrasah merencanakan pengembangan lembaganya pada periode menengah dan jangka/periode panjang. ${ }^{8}$

Beberapa hal di atas membuktikan bahwa pemerintah telah merencanakan sedemikian matang dalam perekrutan tenaga kependidikan yang nantinya akan ditempatkan dilembaga pendidikan. Dalam kegiatan perekrutan tenaga kependidikan pemerintah memberikan lembaga seperti halnya Institut Agama Islam Negeri Madura kewenangan dalam pelaksanaan rekrutmen selain rekrutmen yang dilaksanakan oleh

\footnotetext{
Sudarwan Danim dan Khairil, Profesi Kependidikan, (Bandung: Alfabeta, 2015), hlm., 1. Murip Yahya, Profesi Tenaga Kependidikan, (Bandung: CV Pustaka Setia, 2013), hlm., 18.

6 Muh Fitrah dkk, "Urgensi Sistem Penjaminan Mutu Internal Terhadap Peningkatan Mutu Perguruan Tinggi." Jurnal Penjaminan Mutu, Vol. 4, No, 1 (Februari 2018), hlm.,77.

7 Jamaluddin Iskandar, "Penerapan Manajemen Strategi dalam Peningkatan Mutu Madrasah." Jurnal Idaarah, Vol. 1, No. 2 (Desember 2017), hlm., 270.

8 Ali Nurhadi, (2020) "IMPLEMENTASI MANAJEMEN STRATEGI BERBASIS PEMBIASAAN DALAM MENUMBUHKAN KARAKTER RELIGIUS SISWA DI SMAN 1 GALIS PAMEKASAN", al-Afkar, Journal For Islamic Studies, 3(1, January), pp. 65-76. doi: https://doi.org/10.31943/afkar_journal.v3i1,\%20January.84.
} 
pemerintah. Di Institut Agama Islam Negeri Madura tenaga kependidikan dibagi menjadi tiga bagian yaitu pegawai negeri sipil (PNS), Non pegawai negeri sipil (NonPNS) dan Dosen luar biasa (DLB). Ketiganya memiliki sistem perekrutan yang hampir sama, untuk perekrutan pegawai negeri sipil ditentukan oleh pusat, Non pegawai negeri sipil ditentukan oleh pemerintah dan lembaga, sedangkan untuk pegawai dosen luar biasa ditentukan oleh lembaga. Sehingga dalam perekrutannya lembaga memiliki manajemen strategik tersendiri untuk mendapatkan tenaga kependidikan yang bermutu dan sesuai dengan kebutuhan tenaga kependidikan di lembaga. Oleh karena itu, penulis tertarik untuk mengetahui bagaimana pihak Institut Agama Islam Negeri Madura menerapkan manajemen strategik mutu rekrutmen dalam memperoleh tenaga kependidikan sehingga kegiatan di Institut Agama Islam Negeri Madura berjalan secara efektif dan efisien. Berdasarkan latar belakang masalah yang dikemukakan diatas, maka penulis mencoba untuk melakukan penelitian tentang "Manajemen Strategik Mutu Rekrutmen Tenaga Kependidikan di Institut Agama Islam Negeri Madura".

Penelitian ini terfokus pada bentuk manajemen strategik mutu rekrutmen tenaga kependidikan di Institut Agama Islam Negeri Madura, dan implementasi manajemen strategik mutu rekrutmen tenaga kependidikan di Institut Agama Islam Negeri Madura.

\section{METODE PENELITIAN}

Penelitian ini menggunakan pendekatan kualitatif dengan jenis deskriptif. Sumber data yang diperoleh dengan cara observasi, wawancara, dan dokumentasi. Informannya adalah wakil rektor bidang akademik dan kelembagaan, wakil rektor bidang administrasi umum, perencanaan dan keuangan, kabiro administrasi umum, keuangan, dan akademik, kasubbag umum dan kepegawaian, dekan fakultas tarbiyah, dekan fakultas syari'ah, ketua lembaga penjaminan mutu, dosen dan sumber data sekunder yang terdiri dari foto-foto dan dokumen-dokumen yang berkaitan dengan rekrutmen tenaga kependidikan.

\section{HASIL DAN PEMBAHASAN}

\section{Bentuk Manajemen Strategik Mutu Rekrutmen Tenaga Kependidikan di Institut Agama Islam Negeri Madura}

Berdasarkan hasil wawancara, observasi serta data yang diperoleh kagiatan rekrutmen selama ini cukup baik namun ada beberapa hal yang perlu diperbaiki kaitannya dengan rekrutmen di Institut Agama Islam Negeri Madura, dalam hal ini peneliti menemukan beberapa hal kaitannya dengan rekrutmen di Institut Agama Islam Negeri Madura yaitu:

a. Mutu rekrutmen; berkaitan dengan mutu rekrutmen disini peneliti akan menjelaskan sistematika perekrutan yang dilaksanakan secara umum dan rekrutmen secara lokal atau biasa dikenal dengan rekrutmen calon pegawai negeri sipil dan bukan pegawai negeri sipil: (1) rekrutmen calon pegawai negeri sipil (CPNS). Institut Agama Islam Madura merupakan salah satu Perguruan Tinggi Keagamaan Islam Negeri yang ada di Indonesia, sehingga dalam pelaksanaan rekrutmennya harus melalui rekrutmen yang dilaksanakan pemerintah atau biasa disebut dengan rekrutmen calon pegawai negeri sipil (CPNS), dalam pelaksanaan rekrutmen ini pemerintah yang bertanggung jawab dalam pelaksanaannya dan untuk Institut Agama Islam Negeri Madura membuat daftar kebutuhan tenaga 
kependidikan setelah itu barulah diajukan pada pihak pemerintah untuk ditindak lanjuti. Setelah rancangan kebutuhan tenaga kependidikan selesai maka nantinya pemerintah melakukan pengumuman secara online untuk bisa menarik calon tenaga kependidikan sebanyak mungkin.

Untuk rekrutmen yang dilaksanakan oleh pemerintah ini ada tahapan-tahapannya mulai dari penetapan kebutuhan pegawai, seleksi administrasi, seleksi kompetensi dasar (SKD), dan seleksi kompetensi bidang (SKB) dalam seleksi kompetensi bidang ini termuat tes praktik mengajar, psikotes dan juga wawancara. Hal tersebut juga telah di atur dalam keputusan sekretaris jenderal kementerian agama 6106 tahun 2018 yang mengatur tentang petunjuk pelaksanaan/teknis pengadaan calon pegawai negeri sipil tahung anggaran 2018. (2) Rekrutmen bukan pegawai negeri sipil (Non-PNS). Rekrutmen lokal ini merupakan rekrutmen yang dilaksanakan oleh lembaga tanpa campur tangan pemerintah, baik itu jumlah tenaga kependidikan, cara rekrutmen, pendanaan serta aturan yang digunakan dalam perekrutannya. Untuk perekrutan lokal ini dibagi menjadi dua bagian yaitu rekrutmen dosen luar biasa (DLB) dan rekutmen dosen berkebutuhan khusus. Sistematika rekrutmen dosen luar biasa (DLB) diumumkan secara terbuka melalui website dan melalui selembaran-selembaran yang ditempel di tempat-tempat umum. Hal ini dimaksudkan untuk menarik calon tenaga kependidikan sebanyak mungkin untuk kemudian nantinya dipilih sesuai dengan kebutuhan dan sesuai dengan aturan yang telah ditetapkan oleh lembaga. Proses rekrutmen dosen luar biasa (DLB) di Institut Agama Islam Negeri Madura selama ini cukup baik, dilihat dari proses rekrutmennya sendiri sebelum melaksanakan kegiatan rekrutmen ada beberapa tahapan yang perlu dilakukan untuk memperoleh tenaga kependidikan yang bermutu, untuk menjamin mutu proses dalam kegiatan rekrutmen tenaga kependidikan baik itu melalui kelengkapan administratif, keabsahan berkas, serta melalui tes baik itu tes tulis, wawancara dan mengajar atau praktik sesuai dengan bidangnya masing-masing serta tes baca Al-Qur'an. Untuk tes baca Al-Qur'an ini dirasa sangat perlu untuk mengetahui apakah calon tenaga kependidikan yang melamar memiliki kemampuan baca Al-Qur'an yang baik atau tidak.

Setelah rekrutmen tersebut selesai dilaksanakan dan ternyata pada salah satu mata kuliah tidak ada peminat atau pelamarnya maka dicarilah dosen berkebutuhan khusus yang dapat mengajar sesuai dengan bidang yang dicari oleh Institut Agama Islam Negeri Madura. Untuk teknik perekrutan dosen berkebutuhan khusus itu sama dengan dosen luar biasa hanya saja yang membedakan dari segi kualifikasi akademiknya, untuk dosen luar biasa harus memiliki kualifikasi minimal S2 sedangkan untuk dosen berkebutuhan khusus tidak wajib memiliki kualifikasi S2. Untuk dosen berkebutuhan khusus ini biasanya dibutuhkan pada mata kuliah tertentu yang sifatnya praktik sehingga butuh orang yang profesional untuk bisa mengajar pada mata kuliah tersebut. Seperti pada prodi Komisi Penyiaran Islam (KPI), untuk di Komisi Penyiaran Islam saat ini ada 3 dosen berkebutuhan khusus yang mengajar pada beberapa mata kuliah yang sifatnya praktik. Hal ini dilakukan untuk bisa mengisi kekosongan sekaligus untuk tetap mempertahankan mutu pada setiap mata kuliah yang diampu. Meskipun sebenarnya dosen yang mengajar pada mata kuliah tersebut tidak memiliki kualifikasi S2, akan tetapi sampai saat ini 
kegiatan perkuliahan dapat dikatakan berhasil karena ditangani oleh orang yang professional pada bidangnya.

Sebelum melaksanakan rekrutmen di Institut Agama Islam Negeri Madura terlebih dahulu menyesuaikan dengan kemampuan lembaga dalam membayar tenaga kependidikannya. Karena rekrutmen yang dilaksanakan tidak melibatkan pemerintah dan jumlah gaji yang diberikan menjadi tanggung jawab lembaga bukan menjadi tanggung jawab pemerintah pusat.

b. Sumber rekrutmen; untuk sumber rekrutmen dalam kegiatan rekrutmen bukan pegawai negeri sipil di Institut Agama Islam Negeri Madura pernah menggunakan pihak ketiga atau outsourching dalam merekrut cleaning service, rekrutmen dengan pihak ketiga tersebut tidak bertahan lama dan akhirnya dikembalikan lagi pada aturan institusi.

\section{Implementasi Manajemen Strategik Mutu Rekrutmen Tenaga Kependidikan di} Institut Agama Islam Negeri Madura

a. Sumber daya manusia yang terlibat dalam rekrutmen. Pelaksanaan rekrutmen calon pegawai negeri sipil merupakan tanggung jawab adalah pemerintah begitu pula dengan sumber daya manusia yang melaksanakan rekrutmen tersebut sesuai dengan keputusan pemerintah. Sedangkan dalam pelaksanaan rekrutmen bukan pegawai negeri sipil seperti di Institut Agama Islam Negeri Madura, yang paling berperan merupakan bagian atas baik itu pimpinan, wakil rektor maupun kabiro sedangkan unit bagian bawah kurang berperan serta dalam pelaksanaannya.

b. Kendala dalam rekrutmen. Untuk kendala yang dihadapi dalam kegiatan rekrutmen bukan pegawai negeri sipil yang di laksanakan oleh Institut Agama Islam Madura selama ini tidak serius. Kendala yang dihadapi biasanya ada mata kuliah yang tidak ada pelamarnya, waktu yang digunakan dalam perekrutan cenderung sempit sehingga banyak pelamar yang tidak sesuai dengan persyaratan dan ada beberapa mata kuliah yang peminatnya tidak begitu banyak.

\section{Pembahasan}

Manajemen adalah mencapai tujuan organisasional dengan tepat melaksanakan tugas dan dengan baik menggunakan sumber-sumber melalui pelaksanaan fungsi-fungsi manajemen yang terdiri dari perencanaan, pengorganisasian, pengadaan sumberdaya, pengkomunikasian, pemimpinan, pemotivasian, dan pengendalian atau pengontrolan. ${ }^{9}$ Untuk itu Manajemen strategik bertugas mengendalikan proses yang panjang, mengangkat dan menempatkan orang-orang yang terkait dalam proses itu. Dengan demikian, manajemen strategik adalah manajemen tingkat makro yang berurusan dengan perencanaan strategik dan pengambilan keputusan strategik, sedangkan manajemen lainnya merupakan manajemen tingkat mikro, yaitu menangani hal-hal yang berhubungan dengan pelaksanaan. ${ }^{10}$

Sedangkan Sumber daya manusia atau man power disingkat sumber daya manusia merupakan kemampuan yang dimiliki setiap manusia. Sumber daya manusia terdiri dari daya pikir dan daya fisik setiap manusia. Tegasnya kemampuan setiap

9 Uber Silalahi, Asas-asas Manajemen, (Bandung: PT Refika Aditama, 2013), hlm., 6.

10 Rachmat, Manajemen Strategik, (Bandung: CV Pustaka Setia, 2014), hlm., 13. 
manusia ditentukan oleh daya pikir dan daya fisiknya. sumber daya manusia/manusia menjadi unsur pertama dan utama dalam setiap aktivitas yang dilakukan. ${ }^{11}$

Sumber daya manusia merupakan kebutuhan dari setiap lembaga, untuk memenuhi kebutuhan dari setiap lembaga tentunya setiap lembaga mempunyai cara dan taktiknya sendiri, ada beragam cara untuk mendapatkan calon tenaga kependidikan yang sesuai dengan kebutuhan dari setiap lembaga yang ada. kebutuhan tenaga kependidikan yang semakin meningkat seiring dengan berkembangnya lembaga pendidikan, semakin banyaknya fakultas dengan berbagai program studi yang dimiliki oleh Institut Agama Islam Negeri Madura membuat kebutuhan tenaga kependidikan meningkat. Untuk itu berbagai cara dilaksanakan mulai dari rekrutmen tenaga kependidikan pegawai negeri sipil, non-pegawai negeri sipil sampai dengan pelaksanaan rekrutmen jalur mandiri yang dilaksanakan dengan jalan rekrutmen dosen luar biasa.

Proses rekrutmen meliputi beberapa poin penting menurut Simamora, yaitu: (1) Penyusunan strategi untuk merekrut. Di dalam penyusunan strategi ini, departemen sumber daya manusia bertanggung jawab didalam menentukan kualifikasi-kualifikasi pekerjaan, bagaimana karyawan akan di rekrut, di mana, dan kapan. (2) Pencarian pelamar-pelamar kerja. Setelah rencana dan strategi perekrutan disusun, aktivitas perekrutan sesungguhnya bisa berlangsung, melalui sumber-sumber perekrutan yang ada. banyak atau sedikitnya pelamar dipengaruhi oleh usaha dari pihak perekrutan di dalam menginformasikan lowongan, salah satunya adanya ikatan kerjasama yang baik antara perusahaan dengan sumber-sumber perekrutan eksternal seperti sekolah, universitas. (3) Penyisihan pelamar-pelamar yang tidak cocok. Setelah lamaran-lamaran diterima, haruslah disaring guna menyisihkan individu yang tidak memenuhi syarat berdasarkan kualifikasi-kualifikasi pekerjaan. Di dalam proses ini memerlukan perhatian besar. (4) Pembuatan kumpulan pelamar. Kelompok pelamar (applicant pool) terdiri atas idividu-individu yang telah sesuai dengan kriteria yang telah ditetapkan oleh perekrut dan merupakan kandidat yang layak untuk posisi yang dibutuhkan. ${ }^{12}$

Hal tersebut pada hakikatnya untuk memperoleh tenaga kependidikan sesuai dengan yang di harapkan untuk bisa mencapai tujuan yang diinginkan dalam setiap lembaga pendidikan. Perekrutan lokal yang dilaksanakan oleh Institut Agama Islam Negeri Madura dengan menggunakan media elektronik dan media cetak, media yang digunakan untuk bisa menarik calon tenaga kependidikan sebanyak mungkin untuk kemudian di pilih calon-calon yang memenuhi kriteria. Jika pelaksanaan rekrutmen dilaksanakan oleh pemerintah atau rekrutmen calon pegawai negeri sipil maka pemerintah yang menentukan tempat pelaksanaan rekrutmen tersebut dan jika lembaga sendiri yang melaksanakan rekrutmen atau rekrutmen lokal maka perekrutan dapat ditentukan oleh lembaga.

Secara lebih luas tenaga kependidikan yang dimaksudkan disini adalah sebagaimana termaktub UU No. 20 tahun 2003 tentang sisdiknas, yaitu sebagai berikut: ${ }^{13}$ (a) Tenaga kependidikan terdiri atas tenaga pendidik, pengelola satuan pendidikan, penilik, pengawas, peneliti dan pengembangan di bidang pendidikan, pustakawan, teknisi sumber belajar, dan penguji. (b) Tenaga pendidik terdiri atas

11 Malayu S.P. Hasibuan, Manajemen Sumber Daya Manusia, hlm., 244.

12 Farida Elmi, Telisik Manajemen Sumber Daya Manusia, (Jakarta: Mitra Wacana Media, 2018), hlm., 16-18.

13 Sudarwan Danim dan Khairil, Profesi Kependidikan, hlm., 1. 
pembimbing, pengajar dan pelatih. (c) Pengelola satuan pendidikan terdiri atas kepala sekolah, direktur, ketua, rektor, dan pimpinan satuan pendidikan di luar sekolah.

Termasuk dalam jenis tenaga kependidikan adalah pengelola sistem pendidikan, seperti kepala kantor dinas pendidikan di tingkat provinsi atau kabupaten/kota. Jika mau diperluas, tenaga kependidikan sesungguhnya termasuk tenaga administratif bidang pendidikan, dimana mereka berfungsi sebagai subjek yang menjalankan califungsi mendukung pelaksanaan pendidikan. Dengan demikian, secara umum tenaga kependidikan itu dapat dibedakan menajadi empat kategori yaitu: (a) Tenaga pendidik, terdiri atas pembimbing, penguji, pengajar dan pelatih. (b) Tenaga fungsional kependidikan, terdiri atas menilik, pengawas, peneliti dan pengembang di bidang kependidikan, dan pustakawan. (c) Tenaga teknis kependidikan, terdiri atas laboran dan teknisi sumber belajar. (d) Tenaga pengelola satuan pendidikan terdiri atas kepala sekolah, direktur, ketua, rektor, dan pimpinan satuan pendidikan luar sekolah, dan (e) Tenaga lain yang mengurusi masalah-masalah manajerial atau administratif kependidikan. ${ }^{14}$

Untuk memperoleh tenaga kependidikan tersebut ada beberapa sumber rekrutmen yang perlu dilakukan oleh lembaga pendidikan sesuai dengan cakupan dan kesesuai dengan lembaga tersebut. Dan kaitannya dengan pelaksanaan rekrutmen tenaga kependidikan khususnya Institut Agama Islam Madura memiliki cara tersendiri dalam pelaksanaan rekrutmennya.

Beberapa bentuk rekrutmen, yaitu: (a) Dari surat lamaran masuk (walk-in), (b) Karyawan kontrak atau tenaga outsourching, (c) Refrensi, (d) Hubungan dengan Universitas, (e) Lembaga pendidikan, (f) Memasang iklan di media masa, (g) Memasang iklan di website perusahaan, (h) Bursa tenaga kerja, (i) Agen penyedia tenaga kerja, (j) Asosiasi profesi, (k) Open house, (l) Lingkungan sekitar usaha. ${ }^{15}$

Namun rekrutmen yang dilaksanakan di Institut Agama Islam Negeri Madura melaksanakan rekrutmen lokal dengan mengoptimalkan pada refrensi, website, menggunakan media cetak. Referensi di sini maksudnya Institut Agama Islam Negeri Madura mengoptimalkan rekrutmen melalui orang dalam atau orang-orang yang ada di dalam lembaga, ini dimaksudkan untuk memperoleh tenaga kependidikan yang dibutuhkan dengan waktu yang lebih efien serta tingkat kualitas yang baik tanpa melalui waktu relatif lama. Untuk website sendiri lembaga melakukan pengumuman melalui situs ini agar jaringannya mudah dijangkau secara nasional, dengan menggunakan website ini diharapkan lembaga dapat memperoleh banyak pendaftar dengan waktu yang relatif lebih cepat karena dengan website sendiri informasi tentang rekrutmen akan mudah didapatkan oleh masyarakat luas. Begitu juga dengan menggunakan media cetak, diharapkan masyarakat yang kurang dalam penggunaan teknologi dapat dengan mudah mendapatkan informasi tersebut. Beberapa metode ini dilakukan dengan harapan masyarakat mudah menerima informasi ini dan dengan begitu akan banyak yang mendaftar untuk menjadi calon tenaga kependidikan di Institut Agama Islam Negeri Madura.

Selain menggunakan metode di atas Institut Agama Islam Negeri Madura juga pernah menggunakan pihak ke tiga yakni karyawan kontrak atau tenaga outsourching.

14 Ibid., hlm., 1-2.

15 Karsim, Manajemen Sumber Daya Manusia (Teori dan Praktik), (Jakarta: RajaGrafindo Persada, 2016), hlm., 97-100. 
Tenaga outsourching ini digunakan hanya sementara, setelah itu perekrutan dikembalikan pada kebijakan institusi, untuk tenaga outsourching yang digunakan di Institut Agama Islam Negeri adalah cleaning service. Namun sekarang lembaga sudah kembali pada kebijakan semula, hal ini dilakukan karena pihak lembaga kurang puas dengan sistem yang digunakan, sebenarnya untuk tingkat kedisiplinan tenaga outsourching baik dan mereka juga baik dalam bekerja. Hanya saja loyalitas untuk lembaga kurang sehingga pekerjaan mereka hanya focus pada cleaning service sehingga tidak bisa membantu pekerjaan lain yang ada di lembaga, padahal untuk di lembaga sendiri masih belum terpenuhi keseluruhan tenaga kependidikannya.

Teknik-teknik rekrutmen baik disektor publik maupun swasta, dapat dilakukan melalui cara disentralisasikan atau didesentralisasikan, tergantung kapada keadaan (besarnya) organisasi, kebutuhan dan jumlah calon pekerja yang direkrut.

1. Teknik rekrutmen yang disentralisasikan

Jika rekrutmen disentralisasikan, instansi yang mengelola sumber daya manusia itu bertanggung jawab untuk meminta dari para manajer akan perkiraan-perkiraan periodik mengenai jumlah dan tipe pekerja-pekerja baru yang dibutuhkan diwaktu akan datang. Instansi manajemen sumber daya manusia tingkat pusat akan mengeluarkan pengumuman perihal lowongan kerja yang tersedia untuk memenuhi peraturan perundangan Affimartive Action yang menghendaki perwakilan proporsional maka setiap pengumuman pekerjaan harus memasukkan informasi seperti: ${ }^{16}$ (a) Jenis pekerja, klasifikasi, dan besarnya gaji. Yaitu informasi seperti jenis pekerjaan apa yang akan dilakukan, klasifikasi apa yang dibutuhkan oleh perusahaan, dan besarnya gaji yang ditawarkan oleh perusahaan. (b) Lokasi tugas (unit geografis dan organisasi). Yaitu berkaitan dengan lokasi pekerjaan yang akan dilakukan oleh calon karyawan. (c) Gambaran dari kewajiban-kewajiban kerja. Yaitu memaparkan tentang tugas dan kewajiban yang harus dilakukan calon karyawan ketika ia menempati posisi yang ditetapkan. (d) Kualifikasi minimal. Yaitu kriteriakriteria yang ditetapkan oleh perusahaan dalam merekrut calon karyawan. (e) Tanggal mulai kerja. Yaitu informasi yang memberitahukan kapan calon karyawan dapat memulai kerjanya. (f) Prosedur-prosedur pelamaran. Yaitu aturan-aturan dalam proses perekrutan calon karyawan, guna untuk mempermudah proses perekrutan. ${ }^{17}$

Institut Agama Islam Negeri Madura membuat pengajuan jumlah tenaga kependidikan yang dibutuhkan dengan jumlah yang dibutuhkan, sehingga nanti pusat yang membuat rekrutmen tenaga kependidikannya. Untuk rekrutmen semacam ini lembaga lembaga tidak memiliki hak untuk merekrut sendiri karena sifatnya yang disentralisasi, artinya lembaga hanya membuat rancangan kebutuhan tenaga kependidikan dalam jumlah dan waktu yang dibutuhkan. Yang lebih mengetahui jalannya rekrutmen itu sendiri adalah ketentuan pemerintah.

Sama halnya saat perekrutan dengan menggunakan pihak ketiga, jadi lembaga hanya melakukan perjanjian atau kontrak saja dan yang mencari calon cleaning service tersebut adalah pihak perusahaan, sehingga kontribusi atau loyalitas terhadap lembaga kurang.

2. Teknik rekrutmen yang didesentralisasikan

16 Farida Elmi, Telisik Manajemen Sumber Daya Manusia, hlm., 22.

17 Ibid., hlm., 23. 
Teknik ini terjadi di instansi-instansi yang relatif kecil, kebutuhan-kebutuhan rekrutmen terbatas, dan dalam setiap instansi mempekerjakan berbagai tipe pekerjaan. Rekrutmen dengan cara ini selalu dipakai untuk posisi khas professional, ilmiah, atau administratif bagi suatu instansi tertentu. Instansi-instansi secara sendirisendiri biasanya lebih memilih rekrutmen yang didesentralisasikan karena mereka akan secara langsung mengendalikan proses rekrutmennya. ${ }^{18}$

Setiap perusahaan atau organisasi memiliki formulir lamaran yang biasanya dirancang sendiri sehingga sesuai dengan kebutuhan organisasi/perusahaan tersebut. Formulir lamaran itu dirancang sedemikian rupa sehingga: (a) Berbagai informasi tentang pelamar terdapat didalamnya. (b) Format informasi yang diperoleh seragam yang pada gilirannya memudahkan pemrosesan selanjutnya. ${ }^{19}$

Meskipun setiap organisasi atau perusahaan mempunyai sendiri formulir lamaran yang sifatnya khas karena disesuaikan dengan kebutuhan organisasi atau perusahaan yang bersangkutan sendiri, pengamatan menunjukkan bahwa terdapat kesamaan pada berbagai format yang dikenal sekarang ini. Artinya, jenis informasi yang tertuang dalam formulir lamaran pada dasarnya sama.

Pada umumnya suatu formulir lamaran menggali informasi tentang delapan hal, yaitu data pribadi, status pelamar, keahlian dan keterampilan, riwayat pengalaman, latar belakang kemiliteran, piagam penghargaan, kegemaran atau hobi, referensi. ${ }^{20}$

Jika ada disentralisasi artinya ada didentralisasi, dalam hal ini lembaga memiliki kewenangan untuk menentukan persyaratan dan ketentuan apa saja yang akan digunakan dalam kegiatan rekrutmen tenaga kependidikan. Selain ketentuan yang telah ditetapkan oleh pemerintah, Institut Agama Islam Negeri Madura sebagai salah satu institusi yang memiliki hak untuk menetapkan kewenangannya sendiri namun tetap dalam lingkup pemerintah. Dalam kegiatan rekrutmen di Institut Agama Islam Negeri Madura selama ini sudah baik namun kegiatan rekrutmen khususnya rekrutmen dosen luar biasa masih terbatas oleh kemampuan lembaga dalam masalah pendanaan, selain itu tidak semua fakultas sudah mampu dipenuhi kebutuhan tenaga kependidikannya seperti hanya di fakultas syari'ah yang masih kurang untuk tenaga administrasinya sehingga kegiatan di fakultas syari'ah masih kurang efektif.

Mengevaluasi kesuksesan upaya-upaya perekrutan adalah penting, hal itu adalah cara utama untuk menemukan apakah upaya-upaya tersebut efektif dalam aspek waktu dan uang yang dikeluarkan. Menurut Mathis dan Jackson terdapat hal-hal umum perlu di evaluasi, yaitu

1. Jumlah pelamar, karena tujuan program perekrutan yang baik adalah menghasilkan jumlah pelamar yang besar sehingga dapat dipilih maka kuantitas adalah hal yang alami untuk memulai evaluasi, yang nantinya muncul pertanyaan apakah cukup untuk mengisi lowongan pekerjaan $?^{21}$ Banyaknya pelamar menentukan keberhasilan suatu rekrutmen yang dilaksanakan dalam suatu lembaga pendidikan. Semakin banyak yang mendaftar semakin mudah pula mencari calon tenaga kependidikan yang sesuai dengan kebutuhan lembaga, untuk itu lembaga harus benar-benar

18 Ibid.

19 Sondang P. Siagian, Manajemen Sumber Daya Manusia, (Jakarta: Bumi Aksara, 2015), hlm., 125.

20 Ibid., hlm., 126.

21 Suwatno dan Donni Juni Priansa, Manajemen Sumber Daya Manusia dalam Organisasi Publik dan Bisnis, (Bandung: Alfabeta, 2016), hlm., 75. 
memiliki cara untuk mampu menarik semabanyak mungkin calon tenaga kependidikan.

2. Tujuan EEO yang ingin dicapai. Program perekrutan adalah aktivitas kunci yang digunakan untuk mencapai tujuan merekrut individu-individu dari kelas yang diproteksi, hal ini khususnya relevan ketika sebuah perusahaan benar-benar ingin mencapai tujuan-tujuan seperti itu. Apakah perekrutan menghasilkan para pelamar yang berkualifikasi dengan sebuah campuran yang tepat dari individu-individu dari kelas yang diproteksi.

3. Kualitas pelamar. Di samping kuantitas, harus ditanyakan pula apakah kualifikasi dari kumpulan pelamar adalah cukup untuk mengisi lowongan pekerjaan yang tersedia. Apakah para pelamar memenuhi spesifikasi pekerjaan dan dapatkah mereka melakukan pekerjaan tersebut? ${ }^{22}$ Sebanyak apapun pelamar yang melamar dalam sebuah lembaga namun tidak dapat memenuhi kualitas yang dibutuhkan oleh lembaga maka rekrutmen yang dilakukan tidak dapat dikatakan berhasil. Untuk itu selain dari segi kuantitas lembaga juga akan menilai dejauh mana kualitas yang di miliki pelamar-pelamarnya nanti.

4. Biaya per pelamar yang direkrut. Biaya berfariasi bergantung pada jabatan yang akan diisi, tetapi mengetahui beberapa biaya untuk mengisi sebuah jabatan yang kosong memberikan perspektif tentang tingkat perputaran tenaga kerja (turn over) dan gaji. Biaya yang besar dalam perekrutan adalah biaya memiliki staf perekrutan. Apakah biaya untuk merekrut para tenaga kerja dari berbagai sumber itu mahal ${ }^{23}$ Lembaga pendidikan sebelum melaksanakan rekrutmen biasanya akan melakukan koordinasi terlebih dahulu terkait dengan anggaran yang akan dikeluarkan untuk merekrut tenaga kependidikan. Jika lembaga di rasa mampu untuk merekrut tenaga kependidikan maka rekrutmen tersebut dapat dilaksanakan, namun sebaliknya meskipun lembaga membutuhkan namun berkaitan dengan dana yang akan dikeluarkan maka lembaga akan mencari jalan keluar lain untuk bisa mengatasi hal tersebut.

5. Waktu yang dibutuhkan untuk mengisi jabatan kosong. Lamanya waktunya yang diperlukan untuk mengisi jabatan kosong adalah cara yang lain untuk mengevaluasi upaya-upaya perekrutan. Apakah lowongan pekerjaan cepat diisi oleh para calon yang berkualifikasi sehingga pekerjaan dan produktivitas perusahaan tidak tertunda oleh kekosongan jabatan ${ }^{24}$

Salah satu penentu banyak atau tidaknya pelamar dalam kegiatan rekrutmen yang dilakukan oleh lembaga juga di pengaruhi oleh waktu yang ditentukan, oleh sebab itu semakin panjang waktu pelamaran maka akan semakin banyak orang yang menadaftar namun jika waktu yang diberikan sedikit maka pelamar akan semakin sedikit dan ini juga mempengaruhi tingkat keberhasilan kegiatan perekrutan.

\section{KESIMPULAN DAN SARAN}

Bentuk manajemen strategik mutu rekrutmen tenaga kependidikan di Institut Agama Islam Negeri Madura selama ini cukup baik. Namun, ada beberapa hal yang

\footnotetext{
22 Ibid., hlm., 75-76.

${ }^{23}$ Ibid., hlm., 76.

${ }^{24}$ Ibid.
} 
perlu diperbaiki kaitannya dengan: mutu rekrutmen yang menjelaskan sistematika perekrutan yang dilaksanakan secara umum dan rekrutmen secara lokal, sumber rekrutmen dalam kegiatan rekrutmen bukan pegawai negeri sipil di Institut Agama Islam Negeri Madura pernah menggunakan pihak ketiga atau outsourching dalam merekrut cleaning service dan setelah itu dikembalikan lagi pada aturan Institusi.

Dalam implementasi Manajemen strategik mutu rekrutmen tenaga kependidikan di Institut Agama Islam Negeri Madura selama ini cukup baik, namun perlu adanya perbaikan dari segi: sumber daya manusia yang terlibat dalam rekrutmen di Institut Agama Islam Negeri Madura, yang paling berperan merupakan bagian atas baik itu pimpinan, wakil rektor maupun kabiro sedangkan unit bagian bawah kurang berperan serta dalam pelaksanaannya dan kendala dalam rekrutmen dalam kegiatan rekrutmen lokal yang di laksanakan oleh Institut Agama Islam Madura selama ini tidak serius. Kendala yang dihadapi biasanya ada mata kuliah yang tidak ada pelamarnya, waktu yang digunakan dalam perekrutan cenderung sempit sehingga banyak pelamar yang tidak sesuai dengan persyaratan dan ada beberapa mata kuliah yang peminatnya tidak begitu banyak.

Berdasarkan hasil penelitian yang telah dipaparkan diatas, maka selanjutnya peneliti menyampaikan saran-saran yang kiranya dapat bermanfaat kepada pihak-pihak yang terkait atas hasil penelitian ini. Adapun saran-sarantersebut adalah sebagai berikut: Bagi pihak Institut Agama Islam Negeri Madura diharapkan dapat mempertahankan dan lebih meningkatkan mutu rekrutmen tenaga kependidikan yang sudah baik dan dapat memperbaiki serta meningkatkan mutu rekrutmen tenaga kependidikan yang kurang baik. Bagi peneliti selanjutnya diharapkan tidak hanya berfokus pada bagaimana rekrutmen tenaga kependidikan, namun dapat meningkatkan hal lain melalui implementasi manajemen strategik dalam mutu rekrutmen tenaga kependidikan. Agar penelitian selanjutnya dapat menemukan teori baru yang patut untuk dikembangkan pada penelitian selanjutnya.

\section{DAFTAR PUSTAKA}

Danim, Sudarwan dan Khairil, Profesi Kependidikan. Bandung: Alfabeta, 2015.

Elmi, Farida. Telisik Manajemen Sumber Daya Manusia. Jakarta: Mitra Wacana Media, 2018.

Fitrah, Muh. dkk, "Urgensi Sistem Penjaminan Mutu Internal Terhadap Peningkatan Mutu Perguruan Tinggi.” Jurnal Penjaminan Mutu, Vol. 4, No, 1 Februari 2018.

Iskandar, Jamaluddin. "Penerapan Manajemen Strategi dalam Peningkatan Mutu Madrasah.” Jurnal Idaarah, Vol. 1, No. 2 Desember 2017.

Karsim. Manajemen Sumber Daya Manusia (Teori dan Praktik). Jakarta: RajaGrafindo Persada, 2016.

Nuraeni, Yeni. "Perencanaan Sistem Informasi Penjaminan Mutu Perguruan Tinggi Bidang Sumber Daya Manusia." Journal of Information systems, Vol. 6, No. 1 April 2010.

Nurhadi, Ali. "IMPLEMENTASI MANAJEMEN STRATEGI BERBASIS PEMBIASAAN DALAM MENUMBUHKAN KARAKTER RELIGIUS SISWA DI SMAN 1 GALIS PAMEKASAN", al-Afkar, Journal For Islamic Studies, 3(1, 
January), pp. 65-76. doi: https://doi.org/10.31943/afkar_journal.v3i1,\%20January.84. 2020.

Rachmat. Manajemen Strategik. Bandung: CV Pustaka Setia, 2014.

Rahmawati, Ika Dewi. "Manajemen Sumber Daya Manusia (SDM) dalam Peningkatan Kualitas Sekolah.” Jurnal Manajemen Rekrutmen Tenaga Kependidikan, 2 Oktober, 2012.

Rajaloa, Nani I. dan Rustan Hasim, "Manajemen Perencanaan dan Rekrutmen Tenaga Pendidikan oleh Dinas Pendidikan Kota Ternate." Jurnal Pendidikan, Vol. 16, No. 1, Januari, 2018.

Siagian, Sondang P. Manajemen Sumber Daya Manusia. Jakarta: Bumi Aksara, 2015.

Silalahi, Uber. Asas-asas Manajemen. Bandung: PT Refika Aditama, 2013.

Suwatno dan Donni Juni Priansa. Manajemen Sumber Daya Manusia dalam Organisasi Publik dan Bisnis. Bandung: Alfabeta, 2016.

Yahya, Murip. Profesi Tenaga Kependidikan. Bandung: CV Pustaka Setia, 2013. 